\title{
Response of root explants to in vitro cultivation of marketable garlic cultivars
}

\author{
Danielle C Scotton'; Vagner Augusto Benedito ${ }^{1,2}$; Jeanne B de Molfetta ${ }^{1}$; Benedita Inês FP Rodrigues ${ }^{1}$; \\ Augusto Tulmann-Neto ${ }^{1}$; Antonio Figueira ${ }^{1}$ \\ ${ }^{1}$ USP-CENA, Laboratório de Melhoramento de Plantas; C. Postal 96, Piracicaba-SP; 13400-970; daniscotton@yahoo.com.br; \\ jbmmachado@yahoo.com.br; inesfpr@cena.usp.br; tulmann@cena.usp.br; figueira@cena.usp.br; ${ }^{2}$ West Virginia University, Lab. of \\ Plant Functional Genetics, Genetics and Developmental Biology Program, Plant and Soil Sciences Division, 2090 Agricultural Sciences \\ Building, PO Box 6108, Morgantown WV 26506, USA; vagner.benedito@mail.wvu.edu
}

\begin{abstract}
Garlic cultivars are sexually sterile under standard growth conditions, with direct implications for commercial production costs as well as breeding programs. Garlic is propagated commercially via bulblets, which facilitates disease transmission and virus load accumulation over vegetative generations. Tissue culture produces virus-free clones that are more productive, while keeping the desired traits of the cultivar. Consequently, this technique allows studies of garlic genetics as well as guarantees genetic conservation of varieties. We aimed at analyzing the in vitro regeneration of eight marketable cultivars of garlic using root segments as explants. For each genotype, bulblet-derived explants were isolated and introduced into MS medium supplemented with 2,4-D and 2-iP. Calli were transferred to MS medium supplemented with $8.8 \mu \mathrm{M}$ BAP and $0.1 \mu \mathrm{M}$ NAA (regeneration medium $\mathrm{A}$ ), or with $4.6 \mu \mathrm{M}$ kinetin alone (regeneration medium B). The calli were then evaluated for regeneration frequency after sixty days of in vitro cultivation. The noble cultivar 'Jonas' presented the highest rates of plant regeneration among the cultivars tested. The medium A, which contained auxin and cytokinin, induced the highest regeneration rates of all cultivars. The process described herein is simple, reproducible and can potentially be used as a tool in molecular breeding strategies for other marketable cultivars and genotypes of garlic.
\end{abstract}

Keywords: Allium sativum, bulb, callus induction, organogenesis, regeneration, tissue culture.

\section{RESUMO}

Resposta dos explantes radiculares ao cultivo in vitro de cultivares comerciais de alho

Cultivares de alho são sexualmente estéreis sob condições padrão de cultivo, com implicações diretas nos custos de produção comercial, bem como em programas de melhoramento. O alho é comercialmente propagado por meio de bulbilhos, o que facilita a transmissão de doenças e leva ao acúmulo de cargas virais ao longo das gerações. A cultura de tecidos produz clones livres de vírus que são mais produtivos, mantendo as características desejadas da cultivar. Consequentemente, esta técnica permite estudar a genética do alho, bem como garantir a conservação genética das variedades. Nosso objetivo foi analisar a regeneração in vitro de oito cultivares comerciais de alho usando segmentos de raiz como explante. Para cada genótipo, explantes derivados de bulbilho foram isolados e introduzidos em meio MS suplementado com 2,4-D e 2-iP. Calos foram transferidos para meio MS suplementado com $8,8 \mu \mathrm{M}$ BAP e $0,1 \mu \mathrm{M}$ NAA (meio de regeneração A), ou com 4,6 $\mu \mathrm{M}$ cinetina somente (meio de regeneração B). Os calos foram avaliados quanto à frequência de regeneração após sessenta dias de cultivo in vitro. A cultivar nobre 'Jonas' apresentou as maiores taxas de regeneração entre as cultivares testadas. $\mathrm{O}$ meio de cultura $\mathrm{A}$, o qual continha auxina e citocinina, induziu as maiores taxas de regeneração em todas as cultivares. O processo aqui descrito é simples, reprodutível e pode ser usado potencialmente como uma ferramenta em estratégias de melhoramento para outras cultivares comerciais e genótipos de alho.

Palavras-chave: Allium sativum, bulbo, indução de calos, organogênese, regeneração, cultura de tecidos.

(Recebido para publicação em 27 de dezembro de 2011; aceito em 4 de fevereiro de 2013) (Received on December 27, 2011; accepted on February 4, 2013)

$\mathrm{G}$ arlic (Allium sativum) is a monocot species of the Alliaceae, cultivated mainly in temperate zones around the globe. The Allium genus contains more than 500 members, and garlic is thought to have originated in Central Asia (Etoh et al., 2001). Brazil is one of the largest garlic markets in the world, with most of its garlic production commercialized in natura; yet, there is a trend to increase industrial garlic processing. In 2010 , garlic production reached
17.7 million metric tons worldwide (www.faostat.org), with China as the leading producer (13.7 million metric tons), encompassing almost $80 \%$ of world production. In South America, Argentina is the largest producer, at 128,900 tons. Brazil produced 104,586 tons of garlic in 2010 , ranking at the $13^{\text {th }}$ position. Among the thirty-five leading producers in the world, Tajikistan ranks first in yield (300 t ha-1), China is in fourth place $\left(205 \mathrm{t} \mathrm{ha}^{-1}\right)$, and Brazil ranks at number $20\left(99.2 \mathrm{t} \mathrm{ha}^{-1}\right)$. The world's average yield in 2010 was $132 \mathrm{t} \mathrm{ha}^{-1}$, which indicates that many countries can largely improve yield and production to fulfill the genetic potential of garlic production. However, yield increase will require serious attention to crop management, while making use of optimal agricultural practices and conducting breeding programs to optimize genetic fitness for local cultivation conditions. 
Traditionally, garlic breeding programs have been limited to clonal selection of mutant genotypes, since the almost totality of the species germplasm is sexually sterile. Tissue culture and plant transformation techniques via particle bombardment and Agrobacterium tumefaciens of garlic have been developed, thereby allowing the use of these advances for propagation and breeding programs. Garlic sterility has implications not only for breeding programs, but also directly affects production costs, since garlic cultivation requires expensive vegetative propagules ('cloves') for propagation and enables disease transmission. An efficient method for mass propagation of garlic is therefore highly desirable (Ayabe \& Sumi, 1998). In this regard, the best vegetative propagation method for garlic is using plants originating from in vitro culture, which produces bulbs that are free of viruses, and other diseases and pests.

Somatic embryogenesis and organogenesis have long been studied in garlic (Abo El-Nil, 1977; Nagasawa \& Finer, 1988; Ayabe et al., 1995; Ayabe \& Sumi, 1998; Myers \& Simon, 1998, 1999; Barandiaran et al., 1999a, b; Kondo et al., 2000; Robledo-Paz et al., 2000; Sata et al., 2000; Luciani et al., 2001; Fereol et al., 2002; Luciani et al., 2006; Xu et al., 2008; Lee et al., 2009; Yanmaz et al., 2010). Histological studies on several Alliaceae members (leeks, onions and garlic) have revealed different callus types associated with plant regeneration (Eady et al., 1998; Fereol et al., 2002; Zheng et al., 2003; Luciani et al., 2006; Lee et al., 2009). The most important factors affecting plant regeneration are explant type, the physiological condition of the explant, genotype and the growth regulator combination used in the culture medium. Suh \& Park (1995) used abnormal roots derived from garlic anthers, pedicels, and bulblets as explants to regenerate plantlets. Root tips are also commonly used for garlic regeneration, with or without a callus phase (Barandiaran et al., 1999a, b; Robledo-Paz et al., 2000). Haque et al. (1997, 1999) obtained up to $75 \%$ frequency of direct shoot regeneration from root tips. Regarding callus differentiation and plant development determination by growth regulators, several reports have shown the effects of the synthetic auxins, picloram (4-amino-3,5,6trichloropicolinic acid) and 2,4-D (2,4-dichlorophenoxyacetic acid), on different garlic cultivars (Barandarian et al., 1999b; Myers \& Simon, 1999; Robledo-Paz et al., 2000; Sata et al., 2000; Fereol et al., 2002; Zheng et al., 2003; Luciani et al., 2006).

Genetic improvement programs and genetic research will largely benefit from efficient protocols for garlic plant transformation. So far, only four reports have been published on garlic genetic transformation via the Agrobacterium system. To produce transgenic plants, Kondo et al. (2000) used a vector bearing the report (uidA) and hygromycin (hpt) selection genes on callus explants. Zheng et al. (2004) introduced insect-resistance genes (cry $\mathrm{lCa}$ and $\mathrm{HO} 4$ derived from Bacillus thuringiensis) onto five garlic lines using calli originated from root explants. Eady et al. (2005) describe an Agrobacterium genetic transformation protocol, which uses immature embryos of garlic and leek (Allium ampeloprasum var. porrum). More recently, Kenel et al. (2010) have proposed a modified protocol from the one originally described by Eady et al. (2000), which uses immature leaf tissues via direct regeneration of somatic tissues. This protocol reduces the cultivation period and the possibility of somatic mutations. Herein, we aimed at establishing an efficient in vitro regeneration protocol for marketable varieties of garlic using root segments as explants. We also aimed at exploring the variability of in vitro responses among different varieties of garlic.

\section{MATERIAL AND METHODS}

Plant material- Eight cultivars of garlic (A. sativum) from various Brazilian market groups (noble, semi-noble, common) were classified according to their vegetative cycle length, commercial appearance and mean number of bulblets per bulb. The cultivars used were Amarante-Embrapa, Roxinho 5063, IAC75 - Gigante de
Curitibanos, IAC63 - Mexicano Br and Lavínia 1632 (semi-noble group, medium cycle); Cajuru 2315 (common, early cycle); Cateto Roxo (common, medium cycle); and Jonas (noble group, which requires vernalization). Plant material was obtained from the Germplasm collection at the Instituto Agronômico de Campinas, Campinas, São Paulo state, Brazil.

Culture media - The basic culture medium consisted of full strength MS salts, vitamins (Murashige \& Skoog, 1962) and $30 \mathrm{~g} \mathrm{~L}^{-1}$ sucrose, with the $\mathrm{pH}$ adjusted to 5.8 with $\mathrm{KOH}$ prior to the addition of $2 \mathrm{~g} \mathrm{~L}^{-1}$ Phytagel $^{\circledR}$, and then autoclaved.

In vitro root induction - Bulblets were peeled from their protective leaves and immersed in $70 \%$ ethanol for five minutes, followed by disinfection in $2.5 \%$ sodium hypochlorite (with two drops of Tween 20 per $100 \mathrm{~mL}$ solution) for twenty minutes under constant stirring and ten successive rinses in autoclaved distilled water. Each explant was then excised to expose its $1 \mathrm{~cm}$ apical meristem region and each explant was introduced to a single glass tube $(25 \times 125 \mathrm{~mm})$ with a $20 \mathrm{~mL}$ basic MS medium (introduction medium). The explants were placed in a growth chamber at $27 \pm 2^{\circ} \mathrm{C}$ with a $16 \mathrm{~h}$ light period supplied by fluorescent white lamps at $\sim 31 \mu \mathrm{mol} \mathrm{m} \mathrm{m}^{-2} \mathrm{~s}^{-1}$ for four weeks.

Callus induction - Roots originating in the base of the bulblet after four weeks of in vitro cultivation were then used for callus induction. One-centimeter root segments were cut and transferred to the callus induction medium (a basic MS medium supplemented with $4.5 \mu \mathrm{M}$ 2,4-dichlorophenoxyacetic acid (2,4-D); $0.5 \mu \mathrm{M} \mathrm{N} \mathrm{N}^{6}$-2-isopentenyl adenine (2iP); and $0.2 \mathrm{~g} \mathrm{~L}^{-1}$ casein hydrolysate), as described by Zheng et al. (2003). Each Petri dish with a $25 \mathrm{~mL}$ medium contained twenty-five root segments and each cultivar was represented with ten plates. Cultures were kept in the dark at $27 \pm 2^{\circ} \mathrm{C}$ for two months, when callogenesis was recorded. Subcultures were transferred to fresh media every four weeks.

Plant regeneration - For comparison, calli with $8 \mathrm{~mm}^{2}$ originating from root segments were transferred to 
containers with two distinct regeneration media: medium A, according to Kondo et al. (2000), and medium $\mathrm{B}$, according to Zheng et al. (2003). Both media consisted of a basic MS medium (vitamins and salts). Medium A consisted of MS supplemented with 8.8 $\mu \mathrm{M}$ 6-benzylaminopurine (BAP) and $0.1 \mu \mathrm{M}$ alpha-naphthaleneacetic acid (NAA), while medium B comprised MS supplemented with $4.6 \mu \mathrm{M} \mathrm{N}^{6}$ furfuryladenine (kinetin). Explants were incubated at $27 \pm 2^{\circ} \mathrm{C}$ during a 16-hour photoperiod and transferred to a fresh medium every two weeks. Incubation times varied according to the regeneration medium used: Kondo et al. (2000) reported five months of incubation, whereas Zheng et al. (2003) only incubated explants for two months. The calli were evaluated for shoot regeneration rates, and the two regeneration protocols were compared.

Statistical analysis - For shoot regeneration efficiency, a 2 × 8 factorial design was used (two media and eight garlic cultivars) in a completely randomized experimental design with five replicates. Each replicate was represented by one Petri dish containing twenty-five explants. Data were evaluated using SAS software (SAS Institute Inc., USA) for ANOVA and, when statistically significant, Tukey's test was applied at 5\% probability.

\section{RESULTS AND DISCUSSION}

Callus induction - Root segments were tested for callogenesis, and shown to be responsive explants. Callogenesis was characterized by an initial elongation of the explant, tissue swelling and formation of small callus punctuations in the edges along the whole explant, followed by massive division of undifferentiated cells. The cultivars Cateto Roxo, Cajuru 2315 and Roxinho 5063 did not produce any callus on the callus induction medium at day thirty, but were responsive upon transfer to fresh media, at which point (eight weeks in culture) these explants started to dedifferentiate and form calli. Callogenesis in the other cultivars (Amarante-Embrapa, IAC75 - Gigante de Curitibanos, IAC 63 - Mexicano Br,
Lavínia 1632 and Jonas) was visible at day thirty, and upon transfer to fresh media, they presented vigorous growth. All cultivars showed callogenesis, although at different rates and with distinctive appearances. For 'Jonas', out of 2,500 root segments introduced, more than 1,300 calli were produced, ranking first among all cultivars. 'IAC75 - Gigante de Curitibanos' ranked second with more than 600 calli (Figure 1). According to Zheng et al. (2003), the sole use of auxin in the callus induction medium results in a high callogenesis frequency when compared to the auxin/cytokinin combination. This high induction, however, later resulted in a low regeneration rate. Zheng et al. (2003) also reported callus induction rates of up to $56 \%$ and shoot regeneration of only $6.6 \%$ when treated with auxin alone, in comparison with $33 \%$ callus induction and $31 \%$ shoot regeneration when auxin was combined with cytokinin. In this regard, De Klerk et al. (1997) and Guohua

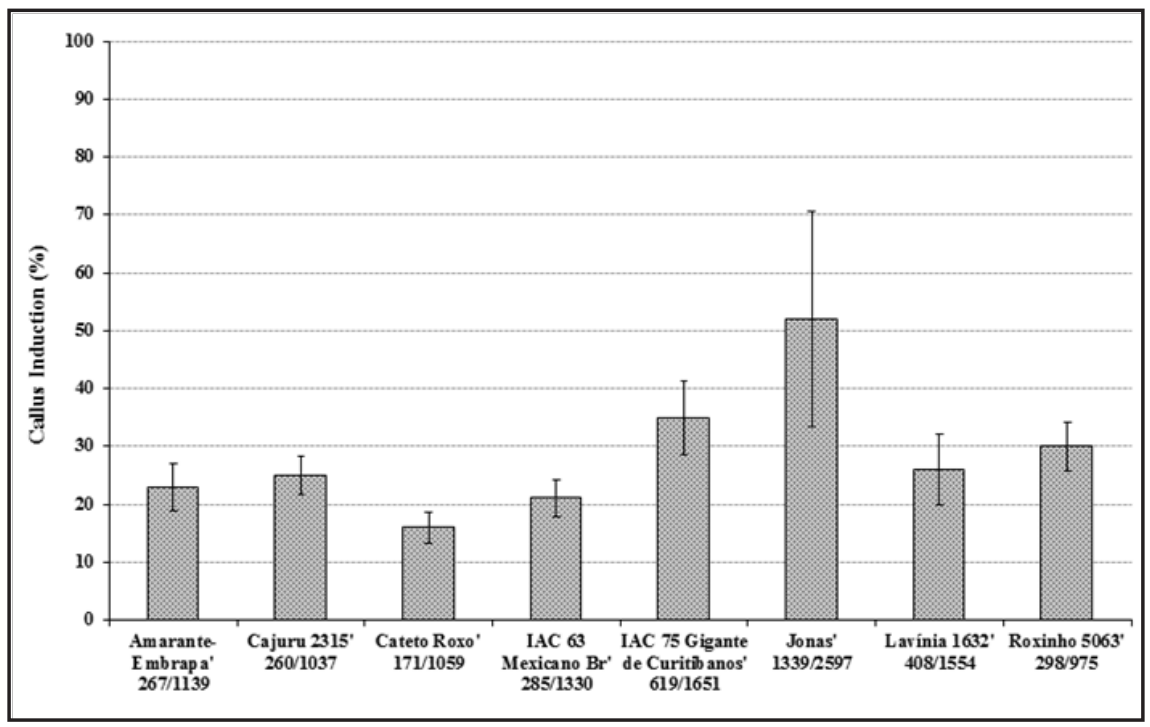

Figure 1. Rate of callogenesis induction in root segments of eight marketable garlic cultivars after 60 days. The percentages were calculated by the number of explants producing calli over the total number of explants introduced in each cultivar. Ten independent replicates were carried out and the average percentages were calculated. The number of introduced explants varied among cultivars due to the availability of plant material, root formation responsiveness and experiment contaminations. The fractions below each variety's name correspond to the total number of responsive calli (numerator) and the total number of calli studied (denominator). Piracicaba, CENA/USP, 2011.

Table 1. Effect of the two regeneration media on callus regeneration in eight garlic cultivars. Piracicaba, CENA/USP, 2011.

\begin{tabular}{lcc}
\hline \multirow{2}{*}{ Cultivars } & \multicolumn{2}{c}{ Responsive calli $\left.\mathbf{( n}^{\mathbf{0}}\right)^{\mathbf{1}}$} \\
\cline { 2 - 3 } & Medium A & Medium B \\
\hline Jonas & $3.57 \mathrm{a}$ & $2.43 \mathrm{a}$ \\
Amarante-Embrapa & $2.57 \mathrm{~b}$ & $1.50 \mathrm{ab}$ \\
IAC 63-Mexicano Br & $2.43 \mathrm{~b}$ & $1.57 \mathrm{ab}$ \\
Cajuru 2315 & $2.43 \mathrm{~b}$ & $1.86 \mathrm{ab}$ \\
IAC 75-Gigante de Curitibanos & $2.29 \mathrm{~b}$ & $1.57 \mathrm{ab}$ \\
Cateto Roxo & $2.14 \mathrm{~b}$ & $2.14 \mathrm{ab}$ \\
Roxinho 5063 & $2.14 \mathrm{~b}$ & $1.29 \mathrm{~b}$ \\
Lavínia 1632 & $2.00 \mathrm{~b}$ & $1.57 \mathrm{ab}$ \\
\hline
\end{tabular}

${ }^{1}$ Averages followed by different letters indicate statistically significant differences according to Tukey's test ( $\mathrm{p}>0.05$ ). Medium A (Kondo et al., 2000); Medium B (Zheng et al., 2003). 
Table 2. Indirect in vitro organogenesis regeneration of eight marketable garlic cultivars. Piracicaba, CENA/USP, 2011.

\begin{tabular}{|c|c|}
\hline Regeneration media & Responsive calli $\left(\mathrm{n}^{0}\right)^{1}$ \\
\hline $\mathrm{MS}+8.8 \mu \mathrm{M} \mathrm{BAP}+0.1 \mu \mathrm{M} \mathrm{NAA}^{2}$ & $2.45 \mathrm{a}$ \\
\hline $\mathrm{MS}+4.6 \mu \mathrm{M}$ kinetin $^{3}$ & $1.74 \mathrm{~b}$ \\
\hline
\end{tabular}

${ }^{1}$ Averages followed by different letters indicate statistically significant differences according to Tukey's test ( $\mathrm{p}>0.05) ;{ }^{2}$ Medium A (Kondo et al., 2000); ${ }^{3}$ Medium B (Zheng et al., 2003).

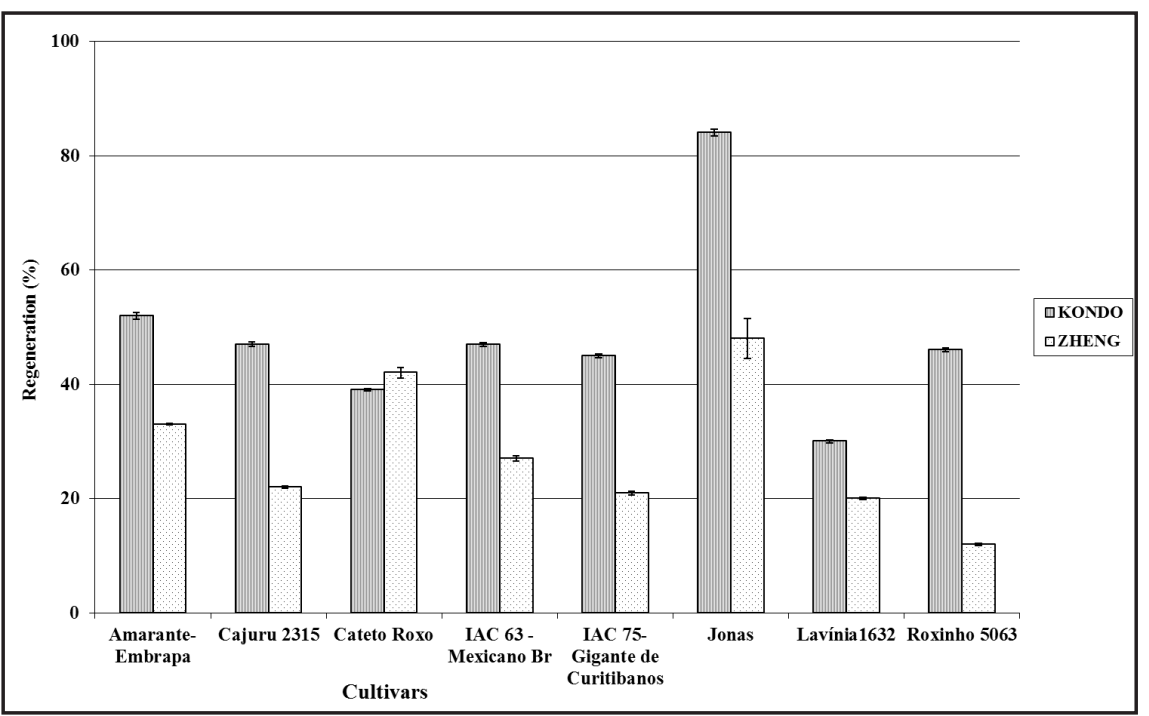

Figure 2. Callus regeneration (\%) in eight garlic cultivars after five months on culture medium A (Kondo et al., 2000) and after two months on culture medium B (Zheng et al., 2003). Piracicaba, CENA/USP, 2011.

(1998) reported that auxins induce callus formation and proliferation as well as somatic embryogenesis, while cytokinins induce mostly shoot and root differentiation and elongation. In keeping with these findings, the auxin/ cytokinin combination in the callus induction medium proposed by Zheng et al. (2003) resulted in an acceptable number of calli for all cultivars analyzed in this study. Our study therefore confirms that this protocol is genotypeindependent.

Plant regeneration - According to Robledo-Paz et al. (2000), the use of root segments as explants highly increases the potential for garlic regeneration. According to Barandiaran et al. (1999a), genotype influences in vitro responsiveness, suggesting that protocols should be optimized for each cultivar. In garlic, in vitro organogenesis occurs indirectly when explants are cultivated in the dark, which provides conditions for callus formation and regeneration of adventitious meristems from callus cells. In our conditions, medium B showed an average of 1.74 (Table 1 and 2). These values might be considered low in terms of in vitro regeneration; however, medium $\mathrm{A}$ showed regeneration rates $40 \%$ higher than medium B. In the regeneration medium supplemented with cytokinin alone (medium B), 'Jonas' also presented the highest regeneration rate (48\%), although lower than its rate for medium A. For medium B, the rate of 'Jonas' differed significantly from that of 'Roxinho 5063', which ranked second for this parameter.

Zheng et al. (2003) noticed that a small amount of cytokinin $(0.5 \mu \mathrm{M}$ $2-\mathrm{iP})$ in the callus induction medium had a stimulating effect on regeneration. The regeneration frequency for media containing auxin alone varied between $6.6 \%$ and $8.9 \%$, whereas the combination of auxin plus cytokinin resulted in $30 \%$ to $48 \%$ regeneration. Interestingly, the cultivar 'Jonas' consistently showed better regeneration than any other cultivar tested, i.e., independently of supplementation by growth regulators in the callus induction medium (Table 1).

In summary, the noble cultivar, 'Jonas' presented the highest rate of plant regeneration among the cultivars tested, and the regeneration medium supplemented with auxin and cytokinin (Kondo et al., 2000) led to the highest regeneration rates for all cultivars. The process herein described is simple, reproducible and can potentially be used for other marketable cultivars and genotypes of garlic for purposes of clonal mass propagation and viral clean up. It can also serve as the basis for producing transgenic garlic for genetic studies, or to be incorporated as a tool in molecular breeding strategies.

The germplasm used in the present study represented various types of Brazilian cultivars. Although these cultivars performed differently upon in vitro culture conditions, the regeneration system reported here is efficient, reliable, and cultivar-independent. Based on previous research using onion, shallot and garlic calli as explants for transformation (Zheng et al., 2001, 2003, 2004), root segment calli from both apical and non-apical tissues are an appropriate starting point for garlic genetic transformation via 


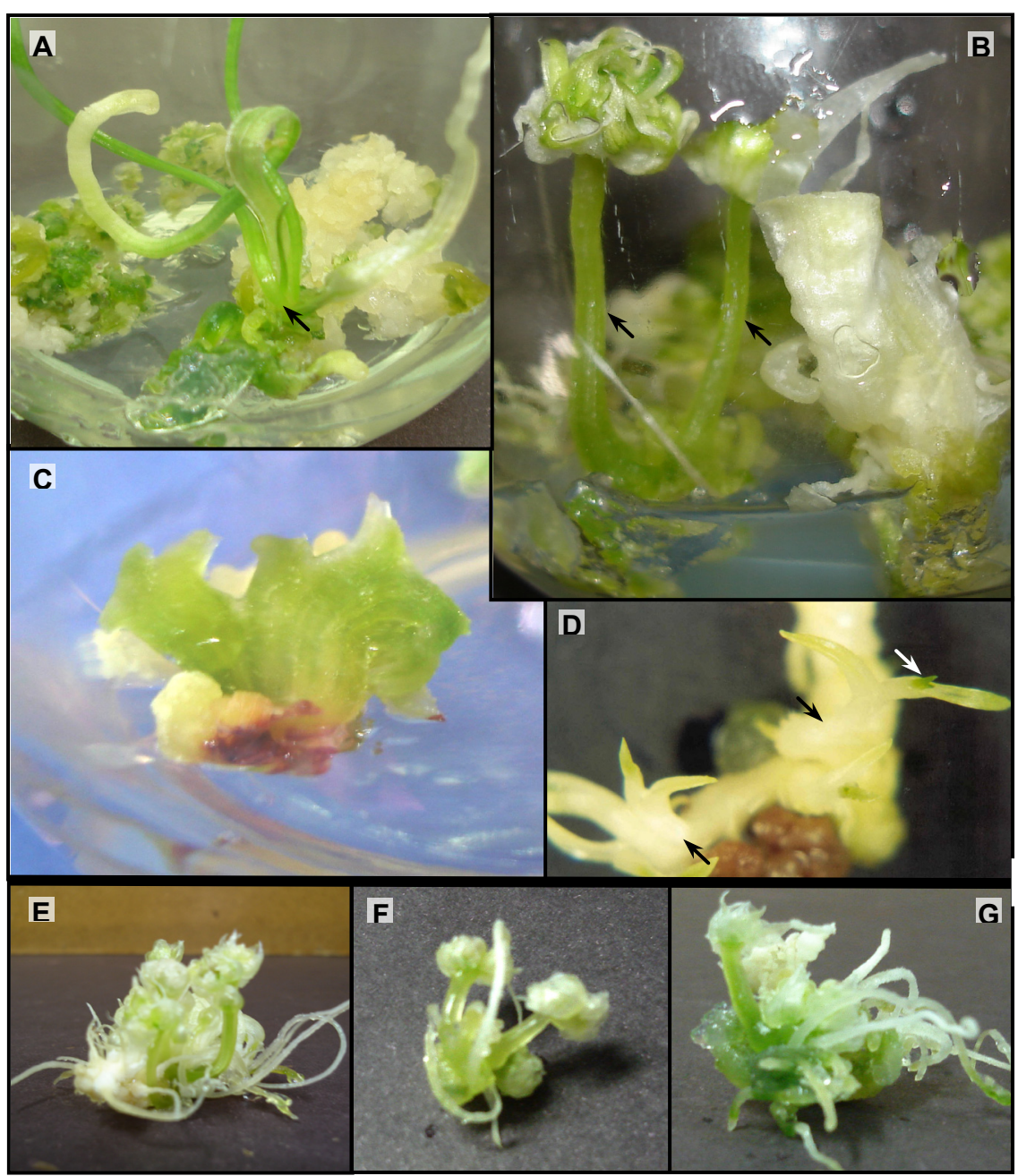

Figure 3. Photos of in vitro shoot development of garlic varieties through indirect organogenesis. Regeneration on medium A (Kondo et al., 2000) (A-D) and medium B (Zheng et al., 2003) (E-G). (A) Developing shoots from cv. 'Amarante-Embrapa' (arrow); (B) cv. 'Jonas' with two shoots (arrows); (C) cv. 'Cajuru 2315' with initial shoot development; (D) Leaf primordia developing from calli of cv. 'Jonas' callus; (E-G) Developing roots and aerial organs from calli of: (E) cv. 'IAC 75-Gigante de Curitibanos'; (F) cv. 'IAC 63-Mexicano Br' and (G) cv. 'Amarante-Embrapa'. Piracicaba, CENA/USP, 2011.

Agrobacterium tumefaciens.

\section{ACKNOWLEDGEMENTS}

Dr. Walter Siqueira, Paulo Trani and Joaquim Azevedo Filho from the Instituto Agronômico de Campinas are acknowledged for supplying plant material. Dr. Raul Almeida and Renato Ferreira are thanked for discussions and for critical reading of the manuscript. The Brazilian Education Minister's agency for High Education Training (CAPES) is acknowledged for providing a fellowship to the first author. Adrienne R. Washington (University of Pittsburgh) is acknowledged for revising this manuscript.

\section{REFERENCES}

ABO EL-NIL MM. 1977. Organogenesis and embryogenesis in callus cultures of garlic (Allium sativum L.). Plant Science Letters 9: 259-264.

AYABE M; TANIGUCHI K; SUMI SI. 1995. Regeneration of whole plants from protoplasts isolated from tissue-cultured shoot primordial of garlic (Allium sativum L.). Plant Cell Reports 15: 17-21.

AYABE M; SUMI S. 1998. Establishment of a novel tissue culture method, stem-disc culture, and its practical application to micropropagation of garlic (Allium sativum L.). Plant Cell Reports 17: 773-779.

BARANDIARAN X; MARTÍNN; RODRÍGUEZCONDE MF; DI PIETRO A; MARTÍN J. 1999a. Genetic variability in callus formation and regeneration of garlic (Allium sativum L.). Plant Cell Reports 18: 434-437.

BARANDIARAN X; MARTÍN N; RODRIGUEZCONDE MF; DI PIETRO A; MARTÍN J. 1999b. An efficient method for callus culture and shoot regeneration of garlic (Allium sativum L.). HortScience 34: 348-349.

DE KLERK GJ; ARNHOLDT-SCHMITT B; LIEBEREI R; NEUMANN KH. 1997. Regeneration of roots, shoots and embryos: physiological, biochemical and molecular aspects. Biologia Plantarum 39: 53-66.

EADY CC; BUTLER RC; SUO Y. 1998. Somatic embryogenesis and plant regeneration from immature embryo cultures of onion (Allium cepa L.). Plant Cell Reports 18: 111-116.

EADY CC; WELD RJ; LISTER CE. 2000. Agrobacterium tumefaciens-mediated transformation and transgenic-plant regeneration of onion (Allium cepa L.). Plant Cell Reports 19: 376-381.

EADY C; DAVIS S; CATANACH A; KENEL F; HUNGER S. 2005. Agrobacterium tumefaciens-mediated transformation of leek (Allium porrum) and garlic (Allium sativum). Plant Cell Reports 24: 209-215.

ETOH T; WATANABE H; IWAI S. 2001. RAPD variation of garlic clones in the center of origin and the westernmost area of distribution. Memoires of the Faculty of Agriculture 37: 21-27.

FEREOL L; CHOVELON V; CAUSSE S; MICHAUX-FERRIERE N; KAHANE R. 2002. Evidence of a somatic embryogenesis process for plant regeneration in garlic (Allium sativum L.). Plant Cell Reports 21: 197-203.

GUOHUA M. 1998. Effects of cytokinins and auxins on cassava shoot organogenesis and somatic embryogenesis from embryo explants. Plant Cell, Tissue and Organ Culture 54: 1-7.

HAQUE MS; WADA T; HATTORI K. 1997. High frequency shoot regeneration and plantlet formation from root tip of garlic. Plant Cell, Tissue and Organ Culture 50: 83-89.

HAQUE MS; WADA T; HATTORI K. 1999. Anatomical changes during in vitro direct formation of shoot bud from root tips in garlic (Allium sativum L.). Plant Production Science 2: 146-153.

KENEL F; EADY C; BRINCH S. 2010. Efficient Agrobacterium tumefaciens-mediated transformation and regeneration of garlic (Allium sativum) immature leaf tissue. Plant Cell Reports 29: 223-230.

KONDO T; HASEGAWA H; SUZUKI M. 2000. Transformation and regeneration of garlic (Allium sativum L.) by Agrobacteriummediated gene transfer. Plant Cell Reports 19: 989-993.

LEE SY; KIM HH; KIM YK; PARK NI; PARK SU. 2009. Plant regeneration of garlic (Allium sativum L.) via somatic embryogenesis. Scientific Research and Essay 4: 1569-1574.

LUCIANI GF; MARINANGELIPA; CURVETTO NR. 2001. Increasing nitrate/ammonium ratio for improvement of garlic micropropagation. Scientia Horticulturae 87: 11-20.

LUCIANI GF; MARY AK; PELLEGRINI C; CURVETTO NR. 2006. Effects of explants and 
growth regulators in garlic callus formation and plant regeneration. Plant Cell, Tissue and Organ Culture 87: 139-143.

MURASHIGE T; SKOOG F. 1962. A revised medium for rapid growth and bio assays with tobacco tissue cultures. Physiologia Plantarum 15: 473-497.

MYERS JM; SIMON PW. 1998. Continuous callus production and regeneration of garlic (Allium sativum L.) using root segments from shoot tip-derived plantlets. Plant Cell Reports 17: 726-730.

MYERS JM; SIMON PW. 1999. Regeneration of garlic callus as affected by clonal variation, plant growth regulators and culture conditions over time. Plant Cell Reports 19: 32-36.

NAGASAWA A; FINER JJ. 1988. Development of morphogenic suspension cultures of garlic (Allium sativum L.). Plant Cell, Tissue and Organ Culture 15: 183-187.

ROBLEDO-PAZ A; VILLALOBOS ARÁMBULA VM; JOFRE-GARFIAS AE.
2000. Efficient plant regeneration of garlic (Allium sativum L.) by root-tip culture. In Vitro Cellular and Developmental Biology-Plant 36: 416-419.

SATA SJ; BAGATHARIA SB; THAKER VS. 2000. Induction of direct somatic embryogenesis in garlic (Allium sativum). Methods in Cell Science 22: 299-304.

SUH SK; PARK HG. 1995. Plant regeneration from the culture of garlic root explants. Journal of the Korean Society for Horticultural Science 36: 31-37.

XU Z; UM YC; KIM CH; LU G; GUO DP; LIU HL; BAH AA; MAO A. 2008. Effect of plant growth regulators, temperature and sucrose on shoot proliferation from the stem disc of Chinese jiaotou (Allium chinense) and in vitro bulblet formation. Acta Physiologiae Plantarum 30: 521-528.

YANMAZ R; YAZAR E; KANTOGLU KY; ALPER A. 2010. In vitro plant regeneration and bulblet formation of Tunceli garlic (Allium tuncelianum (Kollman) Özhatay, Matthew,
Siraneci) by shoot and root culture. Journal of Food, Agriculture \& Environment 8: 572-576.

ZHENG SJ; KHRUSTALEVA L; HENKEN B; SOFIARI E; JACOBSEN E; KIK C; KRENS FA. 2001. Agrobacterium tumefaciensmediated transformation of Allium cepa L.: the production of transgenic onions and shallots. Molecular Breeding 7: 101-115.

ZHENG SJ; HENKEN B; KRENS FA; KIK C. 2003. The development of an efficient cultivarindependent plant regeneration system from callus derived from both apical and non-apical root segments of garlic (Allium sativum L.). In Vitro Cellular and Developmental BiologyPlant 39: 288-292.

ZHENG SJ; HENKEN B; AHN YK; KRENS FA; KIK C. 2004. The development of a reproducible Agrobacterium tumefaciens transformation system for garlic (Allium sativum L.) and the production of transgenic garlic resistant to beet armyworm (Spodoptera exigua Hübner). Molecular Breeding 14: 293-307. 